УдК 616.31-089.444

DOI 10.11603/2411-1597.2020.1.11041

\title{
РЕАНІМАЦІЙНІ ЗАХОДИ: МЕТОДИКА ТА НЕОБХІДНІСТЬ ПРОВЕДЕННЯ
}

\author{
B. С. Тіторчук
}

\author{
Тернопільський національний медичний університет \\ імені І. Я. Горбачевського МОЗ Украӥни
}

Ця стаття включає інформацію про відновлення прохідності дихальних шляхів, підтримку дихання і кровообігу без використання спеціальної техніки в позалікарняних умовах до прибуття спеціалізованої бригади реаніматологів.

\section{RESUSCITATION PROCEDURE: METHODS AND PRACTICAL NECESSITY}

\section{S. Titorchuk}

\section{Horbachevsky Ternopil National Medical University}

This article provides information for the restoration of airway obstruction, the maintenance of breathing and circulation without the use of special equipment in the outpatient setting before the arrival of a specialized group of resuscitators.

Вступ. У наш час все частіше стаються ДТП та нещасні випадки, але не тільки це впливає на причини смертності населення, а й серцево-судинні захворювання, новоутворення, зовнішні причини смерті, хвороби органів травлення, хвороби органів дихання, деякі інфекційні та паразитарні хвороби. Проявляються ці захворювання по-різному і симптоматику мають також різну, в тяжких випадках можливе використання реанімаційних заходів. Ця стадія включає відновлення прохідності дихальних шляхів, підтримку дихання і кровообігу без використання спеціальної техніки в позалікарняних умовах до прибуття спеціалізованої бригади реаніматологів. Реанімаційні заходи потрібно розпочати негайно безпосередньо на місці події. Ефективність реанімаційних заходів залежить від багатьох факторів: уміння медичного персоналу або присутніх на місці події немедиків проведення реанімації; наявності або відсутності дефібрилятора та уміння працювати з ним; терміну виникнення раптової серцевої смерті (РСС) (чим коротший цей період, тим частіше вдається оживити людину) [1].

Основна частина. Перш ніж говорити про серцево-легеневу реанімацію (СЛР), поговорим про те, як у давнину люди намагалися рятувати людину, яка помирала, та про використання штучної вентиляції

(c) В. С. Тіторчук, 2020 легень (ШВЛ). Спроби оживлення вмираючої людини відомі з далеких часів. У своїх ранніх формах реанімація, можливо, така стара, як і людство. Перший опис постурального дренажу при порятунку потопельників можна знайти в папірусах стародавніх єгиптян. Від початку розвитку в епоху іспанської колонізації Америки цей метод отримав широке розповсюдження в Європі та його застосовували, намагаючись оживити раптово померлого, аж до початку XIX століття. Видатний дослідник природи, який жив у середні віки, і медик Андрій Везалій відновлював роботу серця, вводячи повітря в трахею через очеретяну тростинку, тобто за 400 років до опису техніки інтубації трахеї і ШВЛ, основаної на принципі вдування [1]. Перший автоматичний респіратор для проведення ШВЛ був розроблений R. Drager. Його почали випускати в Німеччині у 1911 р. - це був легендарний «Пульмотор». Особливістю респіратора була регуляція циклу вентиляції за тиском. Як колись, так і зараз, реанімаційні заходи постійно вдосконалюють та вносять суттєві зміни в алгоритм серцево-легеневої реанімації [2]. Також реаніматологія спирається на досягнення сучасної техніки - це електронна апаратура, яка сигналізує про порушення функцій різних систем організму, і апарати для підтримки дихання, кровообігу, для очищення крові від шлаків тощо [3]. Реанімаційні заходи при 
раптовій серцевій смерті мають надзвичайно величезне значення, оскільки протягом кількох хвилин вирішується, чи повернеться людина до життя. І в цій екстремальній ситуації медичному персоналу або навіть звичайним людям, присутнім на місці, де трапилася РСС, дуже важливо не розгубитися, не панікувати, а послідовно і правильно оживляти постраждалого. Сьогодні проведення СЛР дозволяє відновити кровообіг у 17,4-61,2 \% пацієнтів після раптової зупинки кровообігу. При цьому 18,5% осіб, які перенесли СЛР, живуть 7 років і більше. Результат серцево-легеневої реанімації залежить від своєчасності та правильності виконання комплексу реанімаційних заходів. Так, щорічно в світі реєструють більше 200 тис. реанімацій в умовах стаціонару, в результаті яких до життя повертають близько 70 тис. пацієнтів (35\% посилити боротьбу). Однак у позалікарняних умовах вдається реанімувати лише $5 \%$ хворих [4].

Одне з найпоширеніших захворювань, яке викликає РСС, - це серцево-судинні захворювання. Хвороби серця займають перше місце серед причин смертності в Україні, випереджаючи навіть рак. Такого високого показника - 68 \% - немає в жодній розви- неній країні світу, а в Європі та Америці ці цифри на порядок нижчі. Основні причини, за якими інфаркти та інсульти почали «досягати» українців у 35-40 років, - неправильне харчування, малорухливий спосіб життя, стреси і шкідливі звички $[5,6]$. Тому сьогодні не тільки Україна, але й весь світ стурбований тим, як «помолодшали» серцево-судинні недуги. Згідно зі статистикою, у 2018 р. серцево-судинні захворювання по Україні склали 52 923,6 на 100 тис. населення; по Запорізькій області - 52 854,4 на 100 тис. населення; по Мелітополю - 58 922,6 на 100 тис. населення (рис. 1).

За 2018 р. смертність від захворювань органів системи кровообігу по місту Мелітополю становила 828,8 на 100 тис. населення; по Запорізькій області - 1 014,7 на 100 тис. населення; по Україні - 982,0. У 66 \% хворих ішемічна хвороба серця поєднується з гіпертонічною, 55 \% від усіх - гострі та повторні інфаркти. Приблизно 60 \% інсультів відбуваються на фоні захворюваності на артеріальну гіпертензію [7]. За даними ВООЗ, Всесвітньої федерації серця та Всесвітньої організації по боротьбі з інсультом, 30 \% випадків смерті від серцевих хвороб є передчасними. 2/3 таких випадків можна уникнути завдяки первинній профілактиці.

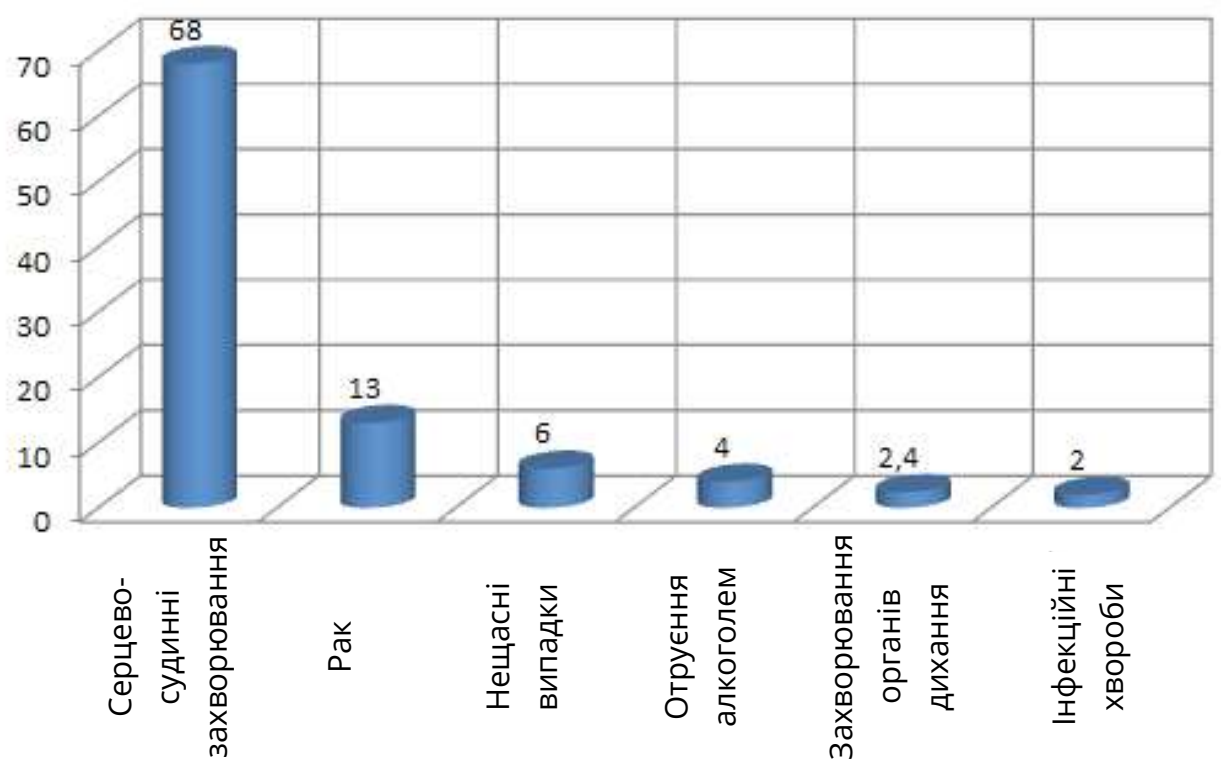

Puc. 1. Причини смертності українців.

Найчастішою причиною смерті від серцевого нападу в дорослих є порушення ритму серця, яке називається фібриляцією шлуночків. Шлуночкову фібриляцію лікують шляхом застосування електричного розряду в ділянці грудної клітки (дефібриляція). Якщо в зоні досяжності немає дефібрилятора, то мозок загине менш ніж за 10 хв. Єдиною можливістю виграти час до того, як стане доступним дефібрилятор, це провести штучне дихання і штучну підтримку циркуляції крові шляхом проведення серцево-легеневої реанімації. Мало хто знає як правильно проводити реанімацію за винятком медичних працівників. Звичайно, щоб надати першу медичну допомогу постраждалому потрібні базові знання, щоб розуміти, як діяти в тій чи іншій ситуації. Проходження курсів, тренінгів, конференцій теж $є$ необхідним, щоб ознайомитися із спеціальними

48 ISSN 2411-1597. МЕДСЕСТРИНСТВО. 2020. № 1 
правилами та нюансами при наданні першої медичної допомоги. Закон України «Про охорону праці» встановлює вимогу, щоб працівники, коли їх приймають на роботу, та в подальшому, періодично проходили за рахунок роботодавця навчання з надання першої медичної допомоги постраждалим від нещасних випадків і правил поведінки у разі виникнення аварії. З'ясуємо, як правильно та безпечно провести серцево-легеневу реанімацію - це є чи не найскладніший за виконанням вид першої допомоги. Рятівник проводить СЛР, щоб відновити життєдіяльність організму постраждалого та вивести його зі стану клінічної смерті. СЛР поєднує компресії грудної клітки, або ж непрямий масаж серця, та штучну вентиляцію легень.

Порядок проведення реанімації [8]:

1) негайно викличіть швидку допомогу за номером 103;

2) підійдіть до постраждалого, доторкніться до нього і голосно заговоріть із ним, наче намагаєтесь розбудити. Не реагує? - Перевірте, чи він дихає. Якщо дихання нормальне, залиште його в тому положенні, у якому знайшли (за умови, що таке положення не становить небезпеки). Спробуйте з'ясувати, що сталося, і надати допомогу;

3) якщо у постраждалого порушене дихання, переверніть його на спину, покладіть на тверду поверхню та послабте одяг, що тисне (ремінь, комірець, краватка). Однією рукою акуратно натисніть на лоб так, щоб підборіддя опинилося на одному рівні з шиєю. Пальцями другої руки підійміть підборіддя, щоб забезпечити максимальну прохідність дихальних шляхів. Зафіксуйте постраждалого у такому положенні - підкладіть йому під лопатки (а не під потилицю) згорнутий у валик одяг;
4) обов'язково перевірте, чи вільні дихальні шляхи: злегка відкрийте рот і загляньте в нього. Якщо в роті рідина (вода, блювотні маси) або сторонні предмети, поверніть його голову на бік і видаліть їх. Далі поверніть голову в початкове положення. Трапляється, що щелепи постраждалого дуже стиснуті й неможливо відкрити йому рота. Тоді виконуйте штучне дихання способом «рот-у-ніс»;

5) станьте на коліна збоку від постраждалого так, щоб ваші ноги були перпендикулярно до його тіла. Не реанімуйте навприсядки або в іншому незручному положенні: за кілька хвилин ви стомитесь, ноги заніміють, і подальша реанімація буде під загрозою;

6) якщо рятуєте вдвох, станьте по різні боки від постраждалого: один навпроти обличчя (виконуватиме штучне дихання - 2 вдування, закриваючи ніс, через кожні 30 натискань), інший - навпроти грудної клітки (для непрямого масажу серця) постійно качає. Через 5-10 хв поміняйтеся місцями. Натискання необхідно проводити за рахунок руху корпусу вниз і вгору, а не за рахунок згинання ліктів. Частота натискань (компресій) 100 мінімум, але не біліше 120 на хвилину, а співвідношення з штучним вдуванням (незалежно від кількості осіб, які проводять серцево-легеневу реанімацію) - 30:2. Глибина компресії повинна бути приблизно 5 см і закінчуватися повним розпрямлянням грудної клітки (рис. 2).

Ваші плечі мають бути точно над грудиною постраждалого. Поштовхи робіть всім корпусом, так м'язи рук менше стомлюватимуться. Коли робите паузу для штучного дихання, прибирайте руки, щоб грудина постраждалого могла безперешкодно підніматися під час вдиху.

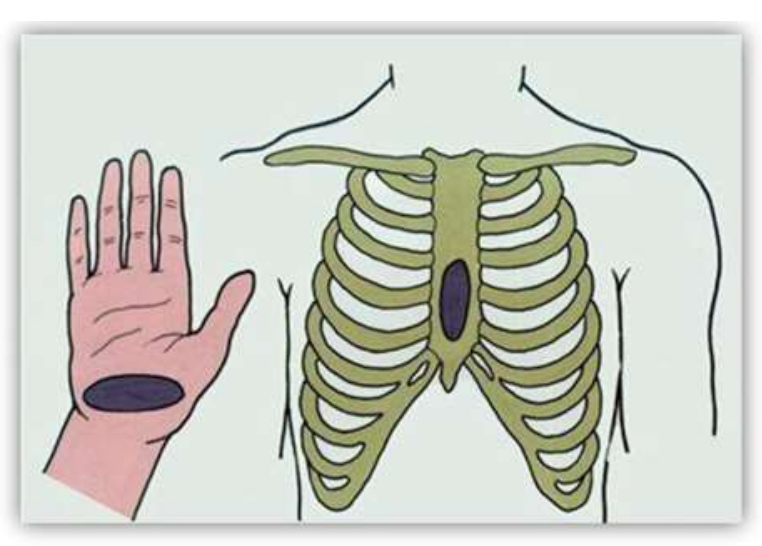

Накладання

рук на грудину

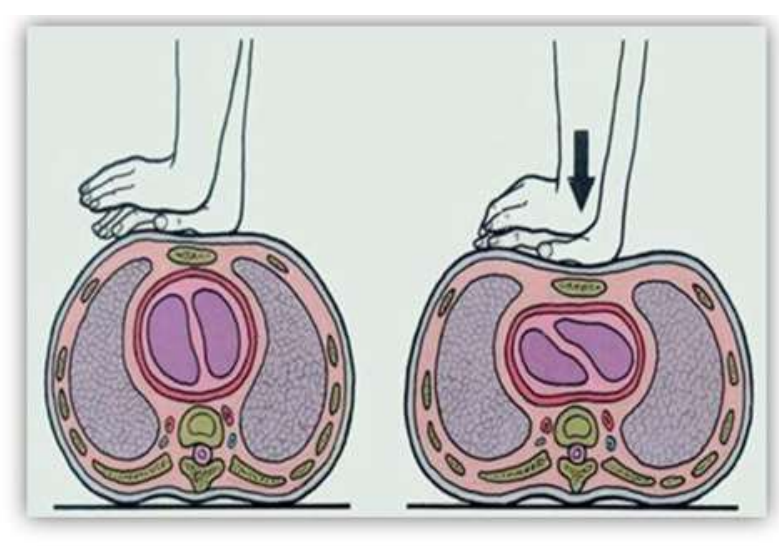

Місце дотику рук

Натискання

на грудину

РUс. 2. Положення рук при непрямому масажі серця. 
7) перед тим, як проводити штучне дихання, затисніть постраждалому носа, щоб повітря надходило йому в легені й не виходило назовні. На рот покладіть одноразовий захисний клапан. Зробіть глибокий вдих із випрямленою спиною і розправленими плечима, щоб набрати повні легені повітря. Потім нахиліться до постраждалого та зробіть видих із зусиллям. Ваш рот при цьому має бути щільно притиснений до рота постраждалого. Повторіть усе ще раз. Ви маєте зробити йому два вдихи (рис. 3).
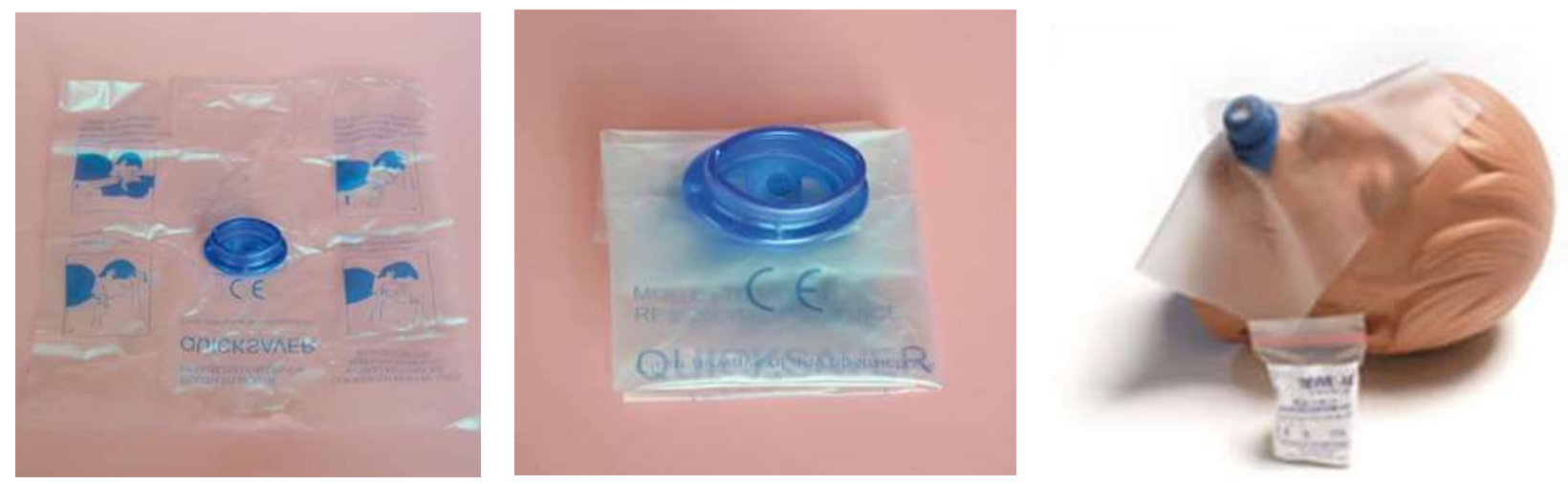

Рис. 3. Маска-клапан для серцево-легеневої реанімації.

Якщо постраждалий не почав рухатись після 5 циклів (приблизно 2 хв) та у Вас $\epsilon$ автоматичний зовнішній дефібрилятор, розташуйте його пластини на тілі пацієнта, підключіть та виконуйте рекомендації. Надайте 1 розряд, потім поверніться до серцево-легеневої реанімації, починаючи з компресій на грудну клітку ще впродовж 2 хв, а потім зробіть 2 розряд. Продовжуйте СлР поки не з'являться ознаки рухів. Коли були використані всі доступні методи і не спостерігались ознаки їі ефективності протягом 30 хв, то продовжуйте СЛР, поки не прибуде медичний персонал (починати підрахунок часу необхідно не від початку проведення СЛР, а з того моменту, коли вона перестала бути ефективною, тобто через 30 хв, протягом яких відсутня електрична активність серця). Тому коли кажуть, що без постачання кисню мозок людини гине за 10 хв, то так воно і $\epsilon$. Іронічно, 10 хв - це стандарт прибуття швидкої на місце виклику в місті, у селі це 20 хв. До прибуття бригади екстреної (швидкої) медичної допомоги кожна хвилина є вирішальною. Тобто, коли ви читаєте, що роль людини, яка стає свідком нещасного випадку, може бути вирішальною - то так воно і $є$. Людина, яка стала свідком якогось випадку, де потрібна СЛР, може врятувати життя.

Висновки. 3 вищесказаного можна зробити висновок, що реанімаційні заходи спрямовані на відновлення і тимчасове заміщення повністю згаслих життєво важливих функцій організму - дихання і кровообігу. Основним завданням цих заходів $є$ підтримка штучного дихання та штучного кровообігу, проведення інтенсивної терапії, спрямованої на відновлення самостійного кровообігу та дихання, нормалізацію функцій центральної нервової системи, печінки, нирок, обміну речовин. Тому реанімаційні заходи $\epsilon$ необхідною і невід'ємною частиною в медицині та в наданні першої медичної допомоги як за кордоном, так і в Україні. Важливо! Жодна публікація не навчить вас здійснювати СлР якісно. Для того, аби це засвоїти, необхідно пройти курс, де під наглядом інструктора ви будете тренуватися до моменту, коли відчуєте, що освоїли техніку правильно.

\section{СПИСОК ЛІТЕРАТУРИ}

1. Сичов О. С. Стандарти надання медичної допомоги хворим із порушеннями ритму та провідності серця (повтор класифікації) / О. С. Сичов, А. О. Бородай, Т. В. Гетьман. - К., 2014. - С. 10.

2. Сіренко Ю. М. Стандарти надання медичної допомоги хворим із легеневою гіпертензією (у дорослих) /

Ю. М. Сіренко, Г. Д. Радченко, Л. Ф. Конопльова // Протоколи ведення реанімаційних хворих. - К., 2012. C. 83.

3. Коваленко В. М. Серцево-судинні захворювання. Класифікація, стандарти діагностики та лікування ; за ред. В. М. Коваленка. - К. : Моріон, 2018. - 223 с. 
4. Теорія і практика інтенсивної терапії / за ред. П. Варги. - 2013. - 87 с.

5. Шукалюк Г. П. Серцево-легенева реанімація: виконуємо вчасно, ефективно, безпечно / Г. П. Шукалюк // Довідник спеціаліста з охорони праці. - 2017. - № 10. С. 60-64.

6. Анестезіологія та інтенсивна терапія : підручник / Ф. С. Глумчер, Л. П. Чепкий, Л. В. Усенко [та ін.]. - 2-ге видання, 2019. - 360 с.
7. Шлапак І. П. Анестезіологія та інтенсивна терапія : підручник / за ред. І. П. Шлапака. - К. : Ніка Прінт, 2013. T. 1. -560 c.

8. Сатишур О. Е. Механическая вентиляция легких / О. Е. Сатишур. - М., 2006. - 352 с.

Отримано 29.01.20 